\title{
Inositol Trisphosphate Releases Intracellularly Stored Calcium and Modulates lon Channels in Molluscan Neurons
}

\author{
Laura A. Fink, ${ }^{1}$ John A. Connor, ${ }^{2}$ and Leonard K. Kaczmarek ${ }^{1,3}$ \\ Departments of ${ }^{1}$ Pharmacology and ${ }^{3}$ Physiology, Yale University School of Medicine, New Haven, Connecticut 06510, and \\ ${ }^{2}$ AT\&T Bell Laboratories, Murray Hill, New Jersey 07974
}

Stimulation of the bag cell neurons of Aplysia triggers a longlasting afterdischarge in these cells. In vivo, such a discharge causes the onset of a sequence of reproductive behaviors. We have found that treatments that trigger discharges in vitro stimulate the hydrolysis of phospholnositides in the bag cell neurons, as measured by increased incorporation of ${ }^{3} \mathrm{H}$-inositol into fractions containing membrane lipids and water-soluble inositol phosphates.

The electrophysiological effects of inositol trisphosphate, one of the products of phosphoinositide turnover that has been shown to mobilize intracellular calcium in non-neuronal cells, were investigated using isolated bag cell neurons in cell culture. Microinjection of inositol trisphosphate into cultured bag cell neurons caused a transient hyperpolarization of the membrane ( $-35 \mathrm{sec})$, together with an increase in conductance. This effect of inositol trisphosphate was abolished by $50 \mathrm{~mm}$ tetraethylammonium ions. Inositol trisphosphate also reduced the amplitude of action potentials. Injection of calcium ions directly into bag cell neurons mimicked these responses seen after inositol trisphosphate injection.

Using the cell-attached patch-clamp technique in conjunction with inositol trisphosphate microinjection, we observed that inositol trisphosphate evoked increases in the activity of a channel carrying outward current at the resting potential and more positive potentials. The estimated slope conductance of the channel modulated by inositol trisphosphate was $\sim 40 \mathrm{pS}$, and its reversal potential was close to that predicted for potassium ions. The increased opening of this channel in response to inositol trisphosphate injection appeared to result from a transient shift of its voltage-dependence to more negative potentials. In a few cases, inositol trisphosphate injection also elicited an increase in the activity of a channel passing inward current at rest.

Direct measurements of changes in intracellular calcium in response to inositol trisphosphate were made using digital imaging of isolated neurons loaded with the fluorescent calcium indicator fura-2. These revealed that injection of inositol trisphosphate significantly elevated intracellular calcium levels, and that this inositol trisphosphate-induced rise in cytosolic calcium was not affected by removal of extracel-

\footnotetext{
Received Aug. 3, 1987; revised Nov. 16, 1987; accepted Nov. 27, 1987.

This work was supported by Grant NS-18492 to L.K.K. We thank Dr. Steven Fisher for the inositol trisphosphate used in some of the experiments.

Correspondence should be addressed to Dr. Kaczmarek, Department of Pharmacology, Yale University School of Medicine, 333 Cedar Street, New Haven, CT 06510.

Copyright (c) 1988 Society for Neuroscience $0270-6474 / 88 / 072544-12 \$ 02.00 / 0$
}

lular calcium. In contrast to the effects of trains of action potentials in calcium-containing media, which produced increases in calcium primarily in neurites, the inositol trisphosphate-induced elevation of calcium appeared more localized to the somata of these neurons.

Our results provide evidence that phosphoinositide-derived second messengers play a role in stimulus-induced discharge in the bag cell neurons and that one of these, inositol trisphosphate, directly mobilizes intracellularly stored calcium ions in these neurons.

The bag cell neurons of Aplysia comprise a well-defined system for studying the long-term modulation of neuronal excitability by second-messenger systems. These neurons are found in 2 discrete clusters in the abdominal ganglion and receive input from the head ganglia via the pleuroabdominal nerves. Although these neurons have relatively negative resting potentials and do not generate any spontaneous electrical activity, brief electrical stimulation of the pleuroabdominal connective or exposure to neuroactive peptides from the atrial gland triggers a prolonged afterdischarge of synchronous action potentials (Kupfermann and Kandel, 1970; Heller et al., 1980). Immediately following stimulation, the bag cell neurons hyperpolarize transiently $(\sim 15-$ $45 \mathrm{sec}$ ) before entering the extended phase of spontaneous firing, which lasts approximately $30 \mathrm{~min}$. During the discharge, the calcium component of the action potentials is enhanced, and the cells secrete several neuroactive peptides that initiate a sequence of reproductive behaviors in the animal (Dudek and Blankenship, 1977; Dudek et al., 1979; Kaczmarek et al., 1982). After the end of the discharge, the cells enter a period of relative inhibition for about $20 \mathrm{hr}$, during which time further stimulation fails to trigger long-lasting discharges (Kaczmarek and Kauer, 1983).

One of the second-messenger systems responsible for the shift in excitability of the bag cell neurons following brief stimulation is the adenylate cyclase system (Kaczmarek et al., 1978; Jennings et al., 1982; Kauer and Kaczmarek, 1985). Another secondmessenger system, linked to the calcium/phospholipid-dependent enzyme protein kinase $C$, may also play a role in the generation of the afterdischarge. Activation of protein kinase $\mathrm{C}$ by phorbol esters or synthetic diacylglycerols, or direct microinjection of the kinase into isolated bag cell neurons, has been shown to enhance action potentials by increasing the calcium current (DeRiemer et al., 1985b). This effect of protein kinase $C$ results from the unmasking of a previously covert species of voltage-dependent calcium channel (Strong et al., 1987). Inhibitors of protein kinase $\mathrm{C}$ have been shown to depress the en- 
hancement of calcium action potentials during a discharge in the bag cell neurons (P. J. Conn, J. A. Strong, and L. K. Kaczmarek, unpublished observations).

Stimulation of protein kinase $\mathrm{C}$ activity is believed to occur in response to physiological stimuli that activate phosphoinositide hydrolysis. Hydrolysis of the membrane lipid phosphatidylinositol 4,5,-bisphosphate to the products diacylglycerol and inositol trisphosphate $\left(\mathrm{IP}_{3}\right)$ constitutes a transmembrane communication system thought to control a variety of cellular functions (Berridge, 1984). Diacylglycerol formed as a result of stimulation can activate protein kinase $\mathrm{C}$ at the plasma membrane (Nishizuka, 1984). $\mathrm{IP}_{3}$, on the other hand, is released into the cytoplasm, where it is believed to act primarily as a stimulus for the release of intracellularly stored calcium (Berridge, 1983; Streb et al., 1983; Berridge and Irvine, 1984). Studies carried out on various excitable cell types, including Aplysia neurons, have described certain electrophysiological effects of $\mathrm{IP}_{3}$ that may result from the release of intracellular calcium (Brown et al., 1984; Fein et al., 1984; Higashida et al., 1986; Sawada et al., 1987).

In this study, we have investigated the regulation of inositol polyphosphate production in the bag cell neurons in response to stimuli that trigger afterdischarge, and we have examined the effects of $\mathrm{IP}_{3}$ on the electrical properties of the bag cells. Moreover, using fura-2 imaging techniques (Connor, 1986; Tsien and Poenie, 1986), we have demonstrated directly that $\mathrm{IP}_{3}$ causes release of intracellularly stored calcium ions in the somata of these neurons.

\section{Materials and Methods}

Phosphoinositide metabolism. Aplysia californica ( $\sim 500 \mathrm{gm})$ were obtained from Alacrity Marine Biological Services and were maintained in artificial seawater (ASW) at $14^{\circ} \mathrm{C}$. The abdominal ganglion was dissected out with the pleuroabdominal connective nerves, and the bag cell clusters and their associated connective nerves were cut away from the rest of the ganglion. For some experiments, the atrial gland was also dissected from the reproductive tract and homogenized in ASW (460 $\mathrm{mm} \mathrm{NaCl}, 10.4 \mathrm{~mm} \mathrm{KCl}, 11 \mathrm{~mm} \mathrm{CaCl}_{2}, 55 \mathrm{~mm} \mathrm{MgCl}, 10 \mathrm{~mm}$ Tris$\mathrm{HCl}, \mathrm{pH} 7.8)$ with protease inhibitors $(250 \mu \mathrm{g} / \mathrm{ml}$ chicken egg white trypsin inhibitor; $250 \mu \mathrm{g} / \mathrm{ml}$ soybean trypsin inhibitor; $25 \mathrm{mg} / 100 \mathrm{ml}$ bacitracin). Both clusters of bag cell neurons were incubated for $2 \mathrm{hr}$ in $200 \mu \mathrm{l} \mathrm{ASW}$ containing $1 \mathrm{mCi} / \mathrm{ml}$ of ${ }^{3} \mathrm{H}$-inositol $(15 \mathrm{Ci} / \mathrm{mm})$. The clusters were then rinsed 5 times in ASW and placed in ASW containing $30 \mathrm{~mm} \mathrm{LiCl}$ for $20 \mathrm{~min}$. Lithium chloride has been shown to amplify the accumulation of inositol phosphates in stimulated tissue (Berridge et al., 1982). Experimental and control clusters were then separated and placed in petri dishes containing fresh $\mathrm{ASW} / 30 \mathrm{~mm} \mathrm{LiCl}$. At this point, one of 3 different treatments was applied. The experimental cluster was either exposed to atrial gland extract for $30 \mathrm{~min}$, to forskolin $(50 \mu \mathrm{M})$ and theophylline ( $1 \mathrm{mM}$ ) for $15 \mathrm{~min}$, or was stimulated electrically for $1 \mathrm{~min}$. Treatment with forskolin and theophylline elevates cAMP levels in the bag cells by $200 \%$ (Kauer and Kaczmarek, 1985). Control clusters were exposed to vehicle or left unstimulated. Electrical stimulation was carried out by placing a suction electrode at the distal end of the pleuroabdominal connective nerve. Stimulus trains were given for $1 \mathrm{~min}$ at a frequency of $6 \mathrm{~Hz}$ and an intensity sufficient to trigger action potentials in the bag cell neurons $(2-10 \mathrm{~V})$. Clusters were homogenized 5 min after stimulation. Experimental and control clusters were each homogenized in $500 \mu \mathrm{l}$ of distilled water. Chloroform/methanol $(1200 \mu \mathrm{l}), 1: 1$ was then added to separate the aqueous and lipid phases. Aliquots of the lipid fraction containing phospholipids that had incorporated ${ }^{3} \mathrm{H}$-inositol were counted directly, and the aqueous fraction was subjected to one of 2 procedures to quantitate water-soluble inositol phosphates.

In most experiments, the aqueous phase was mixed with $500 \mu \mathrm{l}$ of Dowex-1 (formate form) anion-exchange resin, centrifuged briefly ( 1600 $\mathrm{gm}, 30 \mathrm{sec}$ ), and the supernatant was counted as a measure of free ${ }^{3} \mathrm{H}$ inositol. These counts, which, to a large extent, represent as-yet unmetabolized ${ }^{3} \mathrm{H}$-inositol that had been taken up by the cells, were used to estimate the relative sizes of ${ }^{3} \mathrm{H}$-inositol pools available for stimulusinduced hydrolysis in different clusters and to normalize the counts in the inositol phosphate fractions. The resin was then washed 4 times with $4 \mathrm{ml}$ of $5 \mathrm{~mm}$ cold inositol. Finally, $0.5 \mathrm{ml}$ of $0.1 \mathrm{M}$ formic acid/ $1.0 \mathrm{M}$ ammonium formate was added to displace all the inositol phosphates, and aliquots of the supernatant were counted.

In some experiments the aqueous fraction was passed through a $1 \mathrm{ml}$ Dowex-1 anion-exchange column, as described by Berridge et al. (1983), to separate different inositol phosphates. After the aqueous phase was applied to the column, the column was washed with $10 \mathrm{ml}$ of distilled water to remove the free ${ }^{3} \mathrm{H}$-inositol. The counts in these fractions were used to normalize the counts in the inositol phosphate peaks. Four fractions, containing glycerophosphate, inositol-1-phosphate, inositol bisphosphate, and inositol trisphosphate, respectively, were eluted sequentially with $8 \mathrm{ml} 5 \mathrm{~mm}$ sodium borate $/ 60 \mathrm{~mm}$ sodium formate (glycerophosphate), $8 \mathrm{ml} 0.1 \mathrm{M}$ formic acid $/ 0.2 \mathrm{M}$ ammonium formate (IP $), 15 \mathrm{ml} 0.1 \mathrm{M}$ formic acid $/ 0.4 \mathrm{M}$ ammonium formate $\left(\mathrm{IP}_{2}\right)$, and then $8 \mathrm{ml} 0.1 \mathrm{M}$ formic acid/1.0 M ammonium formate $\left(\mathrm{IP}_{3}\right)$.

Cell culture. The method used to prepare isolated bag cells in primary culture was similar to that already described (Kaczmarek et al., 1979). The abdominal ganglion was removed and incubated overnight in a neutral protease solution $(25 \mathrm{mg} / \mathrm{ml})$ for $17 \mathrm{hr}$ at room temperature. The bag cell cluster was then isolated from surrounding tissue, and cells were dispersed with a Pasteur pipette into culture dishes containing modified Eagle's medium (MEM) or Leibovitz medium L15, containing seawater salts. For acute experiments in calcium-free saline, these media were replaced by inorganic saline containing $2 \mathrm{mM}$ EGTA, in which calcium was replaced by magnesium (Connor and Hockberger, 1984).

Electrophysiology and microinjection. Intracellular recordings were made using conventional techniques. Microelectrodes used for injections were filled with $1,4,5,-\mathrm{IP}_{3}\left(0.8 \mathrm{~mm} \mathrm{IP}_{3}, 0.6 \mathrm{M} \mathrm{KCl}\right)$ or calcium (10.0 or $50.0 \mathrm{~mm} \mathrm{CaCl}_{2}, 4.0 \mathrm{M} \mathrm{K}$-acetate), and these solutions were injected into single bag cell neurons by application of pressure to the inside of the electrode (50-250 msec pulses of 20-80 psi) (Kaczmarek et al., 1980). Voltage recordings and current injections were made using either a second, independent $\mathrm{KCl}$-containing electrode in the cell, or, in some cases, using the pressure-injection microelectrode itself. The cells used in these experiments had resting potentials between -35 and $-60 \mathrm{mV}$

Single-channel recordings were made using the cell-attached or insideout patch-clamp technique (Hamill et al., 1981). Pipettes contained ASW. For cell-attached recording, a fire-polished micropipette (0.5-3 $\mathrm{M} \Omega$ ) was first sealed to the cell membrane and the cell was then penetrated with a microelectrode for pressure injection. After being filtered at $100 \mathrm{~Hz}$, single-channel recordings were stored in digitized form and on chart records. In experiments on inside-out, cell-free patches, cellattached pipettes were first withdrawn from cells so as to expose the inner surface of the membrane patch to MEM. The bathing solution was then rapidly exchanged for a solution containing $1.2 \mathrm{mM} \mathrm{MgCl}$, $570 \mathrm{~mm} \mathrm{KCl}, 10 \mathrm{~mm}$ HEPES, $11 \mathrm{~mm}$ glucose, and $0.77 \mathrm{~mm}$ EGTA. Calcium concentrations of $10^{-9}, 10^{-8}, 10^{-7}$, and $10^{-6} \mathrm{M}$ at the cytoplasmic face of the membrane were obtained by adding $0.0,0.07 \mathrm{mM}$, $0.385 \mathrm{~mm}$, and $0.77 \mathrm{mM} \mathrm{CaCl}_{2}$ to this solution.

Calcium imaging. Bag cell neurons growing on \#1 glass coverslips coated with polylysine were loaded with fura- 2 by pressure injection through a microelectrode. Final intracellular fura- 2 concentrations were estimated by comparing the fluorescence $(475-525 \mathrm{~nm}$ ) of loaded cells, using $360 \mathrm{~nm}$ excitation, with that of indicator at known concentrations in glass capillaries whose diameters were close to those of isolated cells. Working indicator concentrations of 30-60 $\mu \mathrm{M}$ were employed. Analytical measurements on single neurons were made with a cooled, charge-coupled device (CCD)-based imaging system described in detail elsewhere (Connor, 1986; Connor et al., 1987a, b). A $25 \times$ glycerine objective was used in the epifluorescence measurements rather than the $40 \times$ one employed in previous work, owing to the large size of the neurons. Fura-2 fluorescence increases maximally with the binding of calcium at $340 \mathrm{~nm}$ excitation and decreases with calcium binding at $380 \mathrm{~nm}$ excitation (Grynkiewicz et al., 1985; Tsien et al., 1985; Williams et al., 1985). The ratio of fluorescence in digitized images taken at 340 and $380 \mathrm{~nm}$ excitation reflects calcium concentrations

After loading cells with the indicator dye, the fura-2-containing microelectrodes were withdrawn and the cells were repenetrated with microelectrodes containing either $\mathrm{IP}_{3}$ in $\mathrm{KCl}$ or $\mathrm{KCl}(0.6 \mathrm{M})$ alone. In a few cases, $\mathrm{IP}_{3}$ was injected iontophoretically, but better results were obtained with pressure injection. Increases in the calcium concentration 


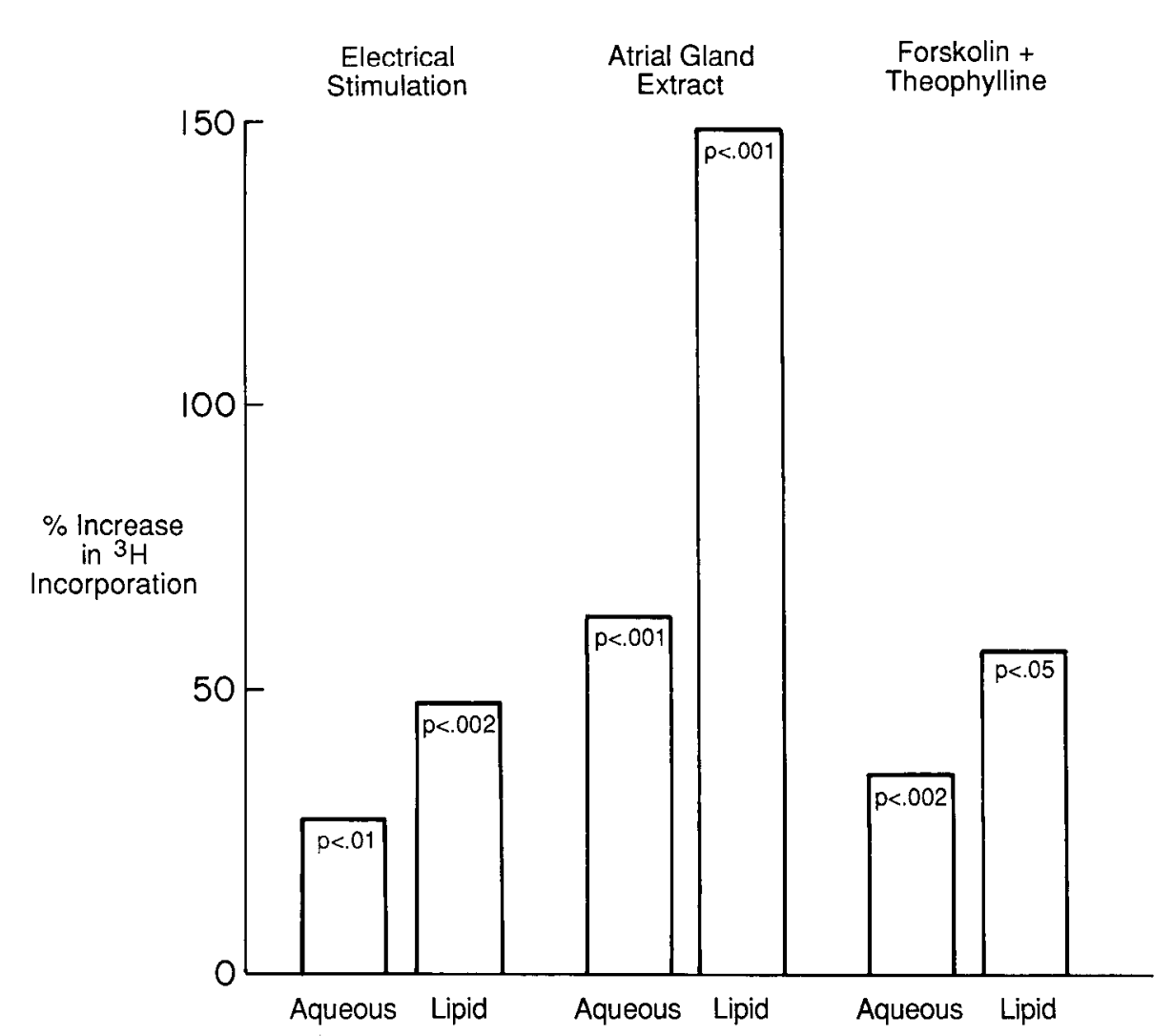

Figure 1. Increases in incorporation of ${ }^{3} \mathrm{H}$-inositol into inositol phosphatecontaining aqueous fractions and into inositol-containing lipid fractions following stimulation of bag cell clusters. Pairs of bag cell clusters were incubated in ${ }^{3} \mathrm{H}$-inositol for $2 \mathrm{hr}$ and then in $\mathrm{LiCl}$ for $20 \mathrm{~min}$. Following stimulation by electrical pulses to the pleuroabdominal connective nerve, exposure to atrial gland extract, or exposure to $50 \mu \mathrm{M}$ forskolin and $1 \mathrm{~mm}$ theophylline, aqueous and lipid fractions were prepared as described in Materials and Methods. Electrical stimulation, $n=7$; atrial gland extract, $n=3$; forskolin theophylline, $n=7$. were deemed significant if there was a noticeable intracellular gradient of calcium following injection of $\mathrm{IP}_{3}$, and if the $340: 380 \mathrm{~nm}$ ratio of fluorescence increased by at least $10 \%$. Images were stored and analyzed with a DEC LSI 11-73-based computer and photographed directly from a video monitor. Indicator fluorescence ratios have been converted to calcium concentrations using the relation,

$$
\left[\mathrm{Ca}^{2+}\right]=K_{\mathrm{d}}\left(\frac{R-R_{\min }}{R_{\max }-R}\right)\left(F_{0} / F_{\mathrm{s}}\right),
$$

where $R_{\min }(0.45)$ and $R_{\max }(11.5)$ are minimum and maximum ratios observed in the apparatus for limiting values of calcium; $F_{0} / F_{\mathrm{s}}$ is the fluorescence ratio for $380 \mathrm{~nm}$ excitation at limiting values of calcium. The indicator dissociation constant $\left(K_{\mathrm{d}}\right)$ of $760 \mathrm{~nm}$ was employed (Grynkiewicz et al., 1985), which, to some extent, takes into account the higher ionic strength encountered when working with marine animals. This $K_{\mathrm{d}}$ was used in calculating calcium levels. The computed calcium levels are coded in false-color, blue to red, signifying low to high levels.

\section{Results}

\section{Phosphoinositide metabolism}

Afterdischarges may be triggered in the bag cell neurons in 3 different ways: (1) brief electrical stimulation of an afferent input, (2) application of atrial gland peptides (Heller et al., 1980), and (3) elevation of intracellular cAMP levels (Kaczmarek et al., 1978; Kauer and Kaczmarek, 1985). We found that all 3 of these treatments stimulated the metabolism of phosphoinositides in intact bag cell clusters, as indicated by increased incorporation of ${ }^{3} \mathrm{H}$-inositol into water-soluble inositol phosphates and into inositol-containing lipids (Fig. 1). Electrical stimulation of an afferent nerve to the bag cells, and elevation of cAMP levels in the cells by forskolin and theophylline, led to similar increases in the production of both inositol phosphates and inositol-containing lipids, whereas atrial gland extract produced a slightly larger response. When fractions containing inositol polyphosphates were further fractionated to separate mono-, bis-, and trisphosphates (with higher phosphates), radioactivity was detected in all 3 fractions.

\section{Electrophysiological effects of inositol trisphosphate injections}

The electrical effects of inositol phosphates were investigated using isolated bag cell neurons in cell culture. Figure 2 illustrates a representative response of the membrane potential of an isolated neuron to a single injection of $\mathrm{IP}_{3}(0.8 \mathrm{~mm}$ in electrode). In this experiment, $\mathrm{IP}_{3}$ injection was followed within a few seconds by a hyperpolarization lasting approximately $60 \mathrm{sec}$ and reaching a peak amplitude of $15 \mathrm{mV}$. Overall, 66 injections of $\mathrm{IP}_{3}$ were carried out in 14 cells at their resting potential $(\sim-45$ to $-60 \mathrm{mV}$ ), and the amplitude of observed hyperpolarizations ranged between 2 and $16 \mathrm{mV}$, with a mean response of $7 \pm 0.4$ $\mathrm{mV}( \pm$ SEM). The duration of the hyperpolarizations ranged between 14 and $75 \mathrm{sec}$ in different cells, with a mean of $35 \pm$ $1.5 \mathrm{sec}$. The cells did not desensitize to $\mathrm{IP}_{3}$. As many as 18 injections were carried out in one cell, and a similar response was elicited by each injection. The hyperpolarization elicited by $\mathrm{IP}_{3}$ could be eliminated by the potassium channel blocker tetraethylammonium ions (TEA; 50-100 mM) in the extracellular medium ( $n=4$; Fig. 2). The response to $\mathrm{IP}_{3}$ could not be mimicked by injections of myo-inositol, inositol-1-phosphate, inositol-1,3,4,5 tetrakisphosphate, ATP, or $\mathrm{KCl}$.

Figure $2 b$ shows that the $\mathrm{IP}_{3}$-induced hyperpolarization occurred with an increase in membrane conductance. At the peak of the hyperpolarization, the input resistance of this cell, measured by the amplitude of voltage deflections elicited by constant hyperpolarizing current pulses, was decreased by $20 \%$. Input resistance was monitored during $25 \mathrm{IP}_{3}$ injections in 12 cells, and the mean decrease was $26 \pm 3.5 \%$. The effect of $\mathrm{IP}_{3}$ on input resistance was not due to the shift in membrane potential, 


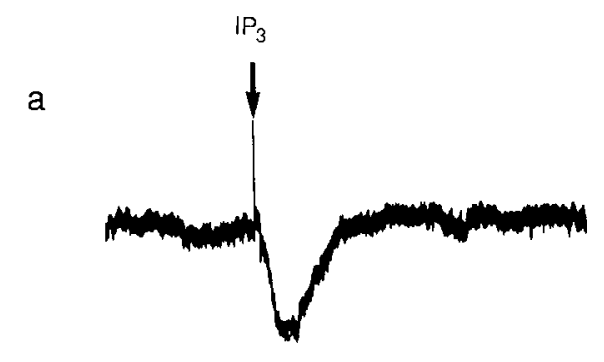

b

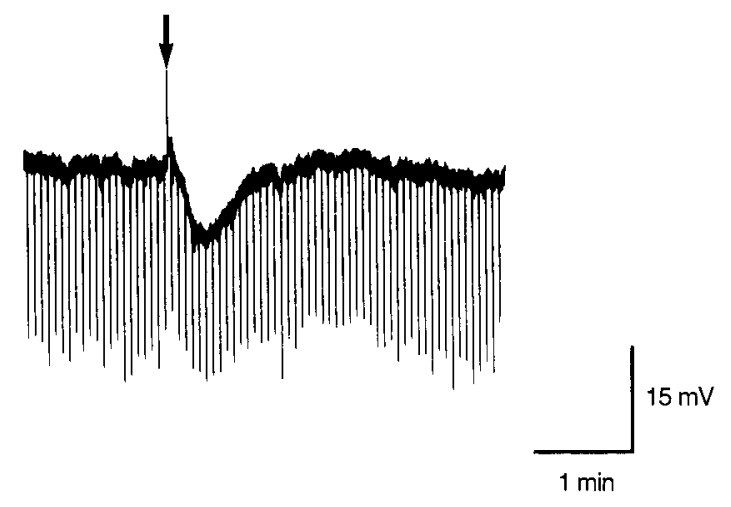

c
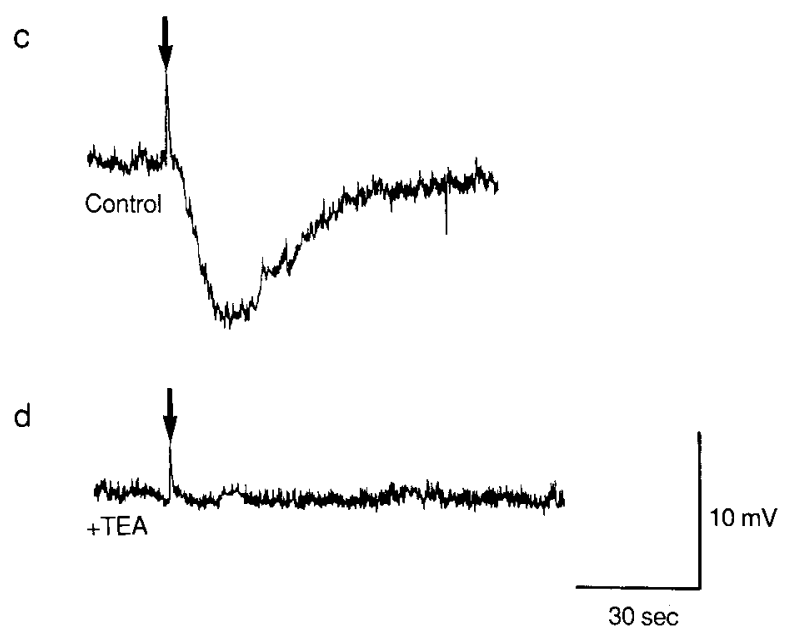

Figure 2. Voltage recordings of isolated bag cell neurons in culture injected with $\mathrm{IP}_{3}$. $a$, Hyperpolarizing voltage response of a bag cell neuron to intracellular pressure injection of $\mathrm{IP}_{3}($ arrow $) . b$, $\mathrm{IP}_{3}$ injection in the same cell produces an increase in membrane conductance, measured by a reduction in the voltage response of the cell to constant hyperpolarizing current pulses. $c, d$, Response to $\mathrm{IP}_{3}$ injection in a different cell before $(c)$ and after $(d)$ exposure to $50 \mathrm{mM}$ TEA.

because passive hyperpolarization of cells by up to $16 \mathrm{mV}$ with current injection did not significantly lower input resistance.

Figure 3 shows that injection of $\mathrm{IP}_{3}$ also attenuated the size of action potentials evoked by depolarizing current pulses. Figure $3 a$ illustrates action potentials elicited before $\mathrm{IP}_{3}$ injection. Figure $3 b$ was recorded $10 \mathrm{sec}$ after injection, and the action potentials are clearly diminished in height. Recovery, shown in Figure $3 c$, was evident within $2 \mathrm{~min}$. In some cases, as in Figure 3 , recovery was associated with a rebound enhancement of action potential height, but this was not observed in all experiments. As with the effect of $\mathrm{IP}_{3}$ on input resistance, passive hyperpolarization of the cell membrane could not mimic the reduction in the amplitude of action potentials induced by $\mathrm{IP}_{3}$.
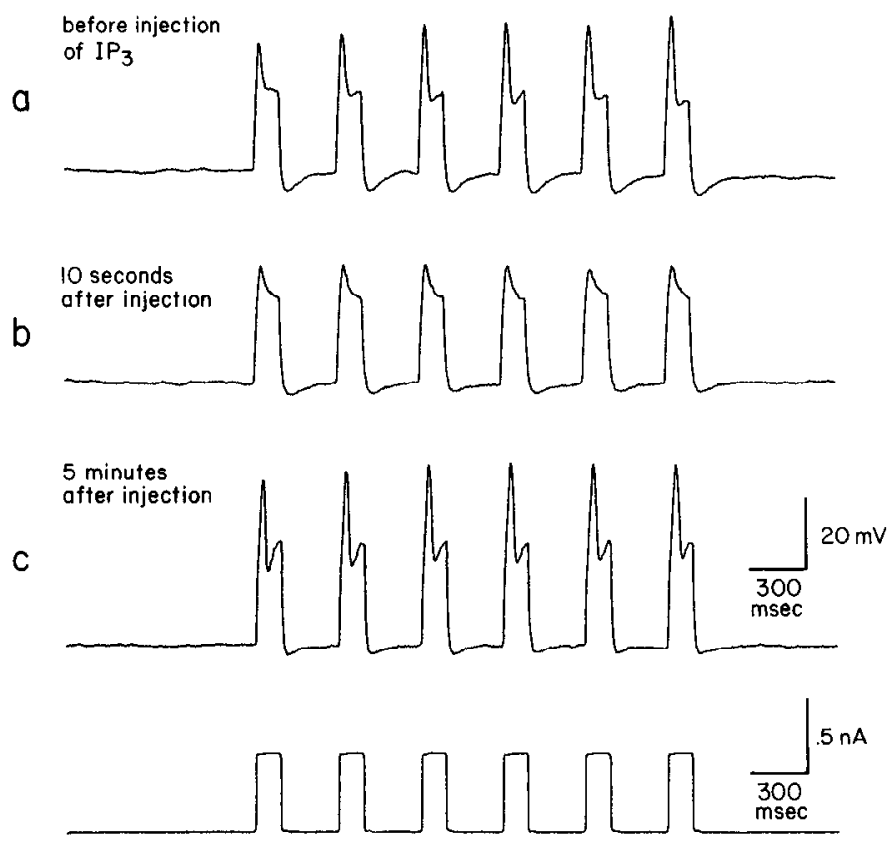

Figure 3. Effect of $\mathrm{IP}_{3}$ injection on the amplitude of action potentials evoked by depolarizing current pulses (lowest trace). a, Action potentials elicited by depolarizing current pulses before injection of $\mathrm{IP}_{3} . b$, Action potentials are greatly attenuated following $\mathrm{IP}_{3}$ injection. $c$, Recovery is evident within $5 \mathrm{~min}$ after injection.

Control injections of myo-inositol, inositol-1-phosphate, ATP, or $\mathrm{KCl}$ did not significantly influence input resistance or the amplitude of action potentials.

The characteristics of the response of isolated bag cell neurons

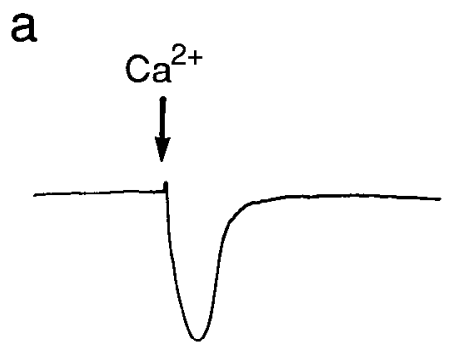

b

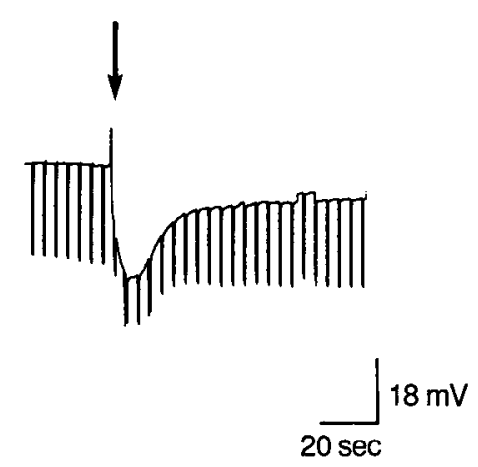

Figure 4. Voltage recordings from an isolated bag cell neuron injected with calcium chloride. $a$, Intracellular pressure injection of calcium chloride transiently hyperpolarizes the cell. $b$, Injection of calcium chloride produces an increase in membrane conductance, measured as a decrease in the voltage response to a train of constant hyperpolarizing current pulses. 
A

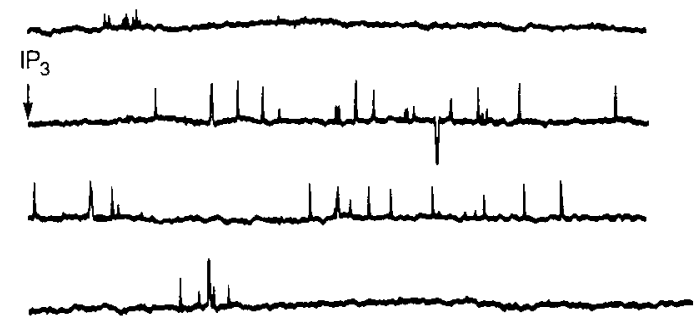

Figure 5. Effect of $\mathrm{IP}_{3}$ injection on single-channel activity recorded in cell-attached patches on isolated bag cell neurons. $A$, In a patch maintained $50 \mathrm{mV}$ positive to rest, $\mathrm{IP}_{3}$ elicits the repeated opening of an outward channel presumed to be a calcium-activated potassium channel. $B$, Pooled data from 3 experiments illustrating the time course of the opening of single channels passing outward current following $\mathrm{IP}_{3}$ injection.

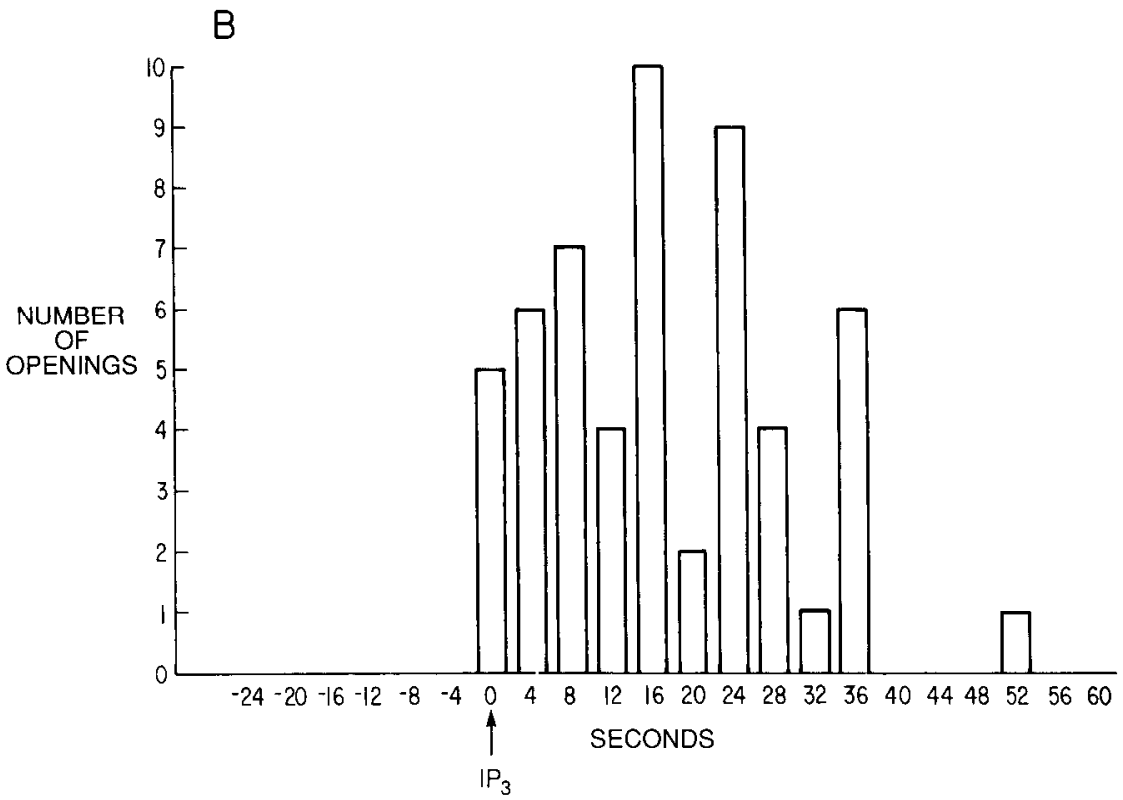

to $\mathrm{IP}_{3}$ injection, in particular the amplitude and duration of the $\mathrm{IP}_{3}$-induced hyperpolarization, closely match those of the transient hyperpolarization that is observed immediately following stimulation that triggers a subsequent afterdischarge in intact clusters of bag cell neurons within the abdominal ganglion. Moreover, the transient hyperpolarization in the intact system is eliminated by $50-100 \mathrm{mM}$ TEA, and is associated with a depression of action potential amplitude (Kaczmarek et al., 1982, and unpublished observations), as is the $\mathrm{IP}_{3}$-induced hyperpolarization. Nevertheless, because selective inhibitors of $\mathrm{IP}_{3}$ formation are lacking, the relationship between the $\mathrm{IP}_{3}$ response of isolated neurons and the stimulus-induced hyperpolarization in intact clusters cannot be tested definitively.

\section{Intracellular injection of calcium ions}

The electrical effects of $\mathrm{IP}_{3}$ injection in isolated bag cell neurons could be mimicked by direct injection of calcium ions. Figure 4 illustrates an example in which calcium injection produced a hyperpolarization that lasted about $40 \mathrm{sec}$. Figure $4 b$ shows that the input resistance of the cell decreased following calcium injection and recovered with the same time course as the membrane potential. Nineteen injections of calcium chloride in 8 cclls clicitcd a mean hypcrpolarization of $18 \pm 2.8 \mathrm{mV}$. The mean duration of the response was $37 \pm 11.3 \mathrm{sec}$, and the input resistance measured after 4 injections in 2 cells was reduced by $49 \%$ at the peak of the hyperpolarization. Calcium injection also attenuated the size of action potentials by $47 \%$ ( 3 injections in 2 cells). The response to calcium was usually more rapid in onset than that to $\mathrm{IP}_{3}$ injection.

\section{Single-channel recordings}

To investigate the single-channel events underlying the electrical effects of $\mathrm{IP}_{3}$ and calcium injections, cells were penetrated with an $\mathrm{IP}_{3}$ or calcium-containing microelectrode after a patch electrode was sealed to the membrane for cell-attached recording. Figure $5 A$ shows a continuous current recording from a membrane patch held $50 \mathrm{mV}$ positive to rest before and after injection of $\mathrm{IP}_{3}$. Few openings were observed during the $16 \mathrm{sec}$ prior to $\mathrm{IP}_{3}$ injection. However, after the injection, the activity of a channel carrying outward current increased for a period of 34 sec and then subsided. Figure $5 B$ represents data pooled from 3 experiments, showing that the time course of the increase in such single-channel openings elicited by $\mathrm{IP}_{3}$ injection matched the time course of $\mathrm{IP}_{3}$ effects observed in the current-clamp experiments. In total, 31 injections in 7 cells elicited dramatic increases in outward channel activity at rest and at potentials up to $+100 \mathrm{mV}$ positive to rest. The latency from the timc of injection to the increase in observed channel openings varied 

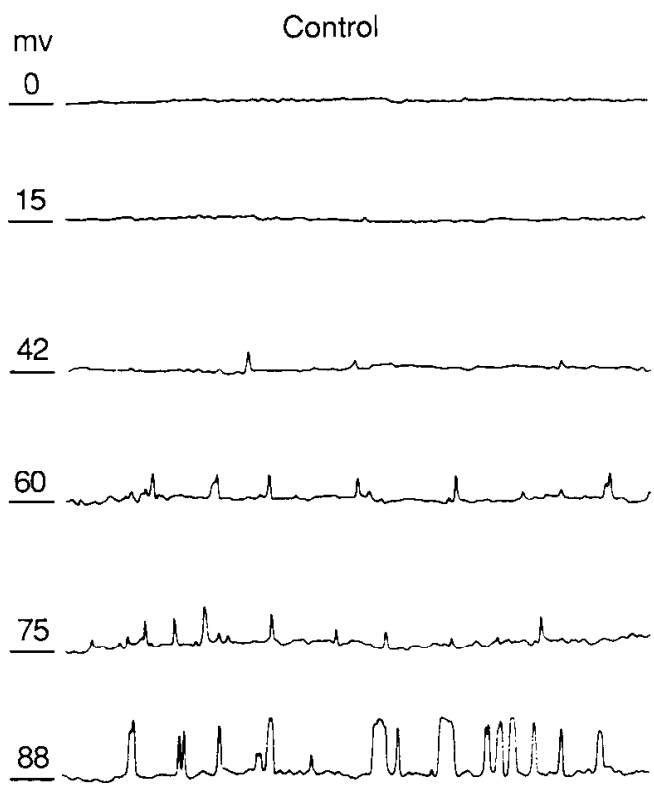

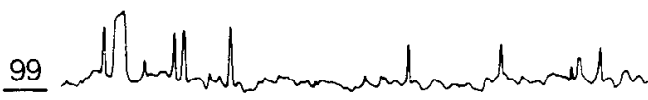

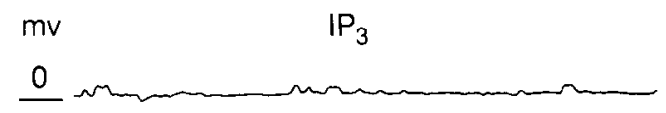

16

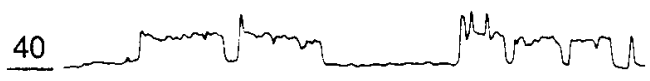

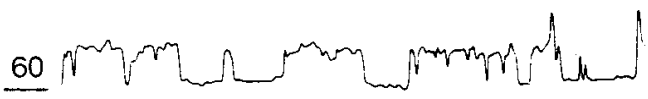

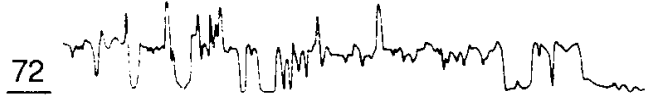

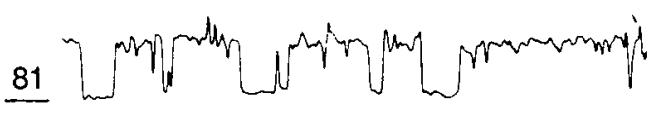

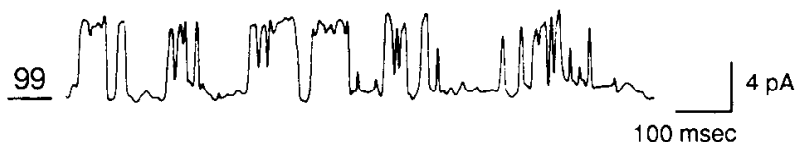

Figure 6. $\mathrm{IP}_{3}$ induces an alteration in the voltage-dependence of channel activity recorded in cell-attached patches. Traces are representative examples of the probability of opening of the $\mathrm{IP}_{3}$-modulated channel, before and after $\mathrm{IP}_{3}$ injection, at several different voltages. The values for the holding potentials of the patch are shown next to the individual traces and are given relative to the resting potential, such that the top traces are at the resting potential. After $\mathrm{IP}_{3}$ injection, the probability of the channel's opening is increased at all voltages examined.

from 2 sec to approximately 1 min, but was most often less than $15 \mathrm{sec}$. The increase in the probability of channel opening usually lasted between 20 and $80 \mathrm{sec}$, but in 2 cases the response was prolonged for 3-4 min. Figure 6 demonstrates that the channel opened by $\mathrm{IP}_{3}$ injection is also gated by voltage, and that the $\mathrm{IP}_{3}$-induced increase in channel activity results from an alteration in the voltage dependence of channel opening. Figure 6 shows recordings from a cell-attached patch before and after $\mathrm{IP}_{3}$ injection at 7 voltages. Prior to $\mathrm{IP}_{3}$ injection, prolonged channel openings occurred to a significant extent only at positive potentials (60-100 $\mathrm{mV}$ positive to rest). $\mathrm{IP}_{3}$ injection was followed by an increase in the probability of opening at all holding

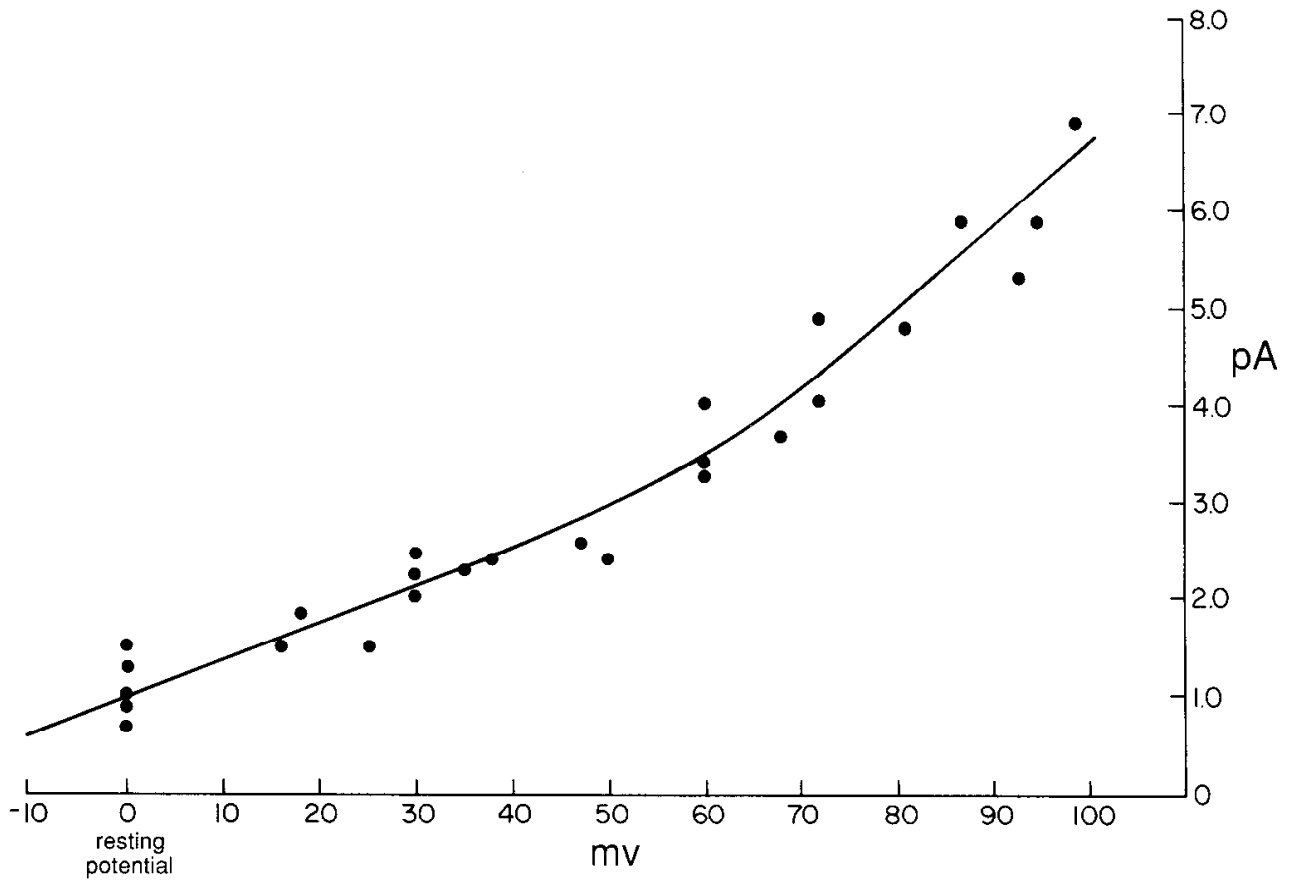

Figure 7. Current-voltage relation of the channel modulated by $\mathrm{IP}_{3}$. Data shown were obtained following 2 separate injections of $\mathrm{IP}_{3}$ in the same cell. The estimated slope conductance of the channel is $\sim 40 \mathrm{pS}$ and the extrapolated reversal potential is close to $E_{\mathrm{k}}$. No corrections were made for membrane potential changes due to $\mathrm{IP}_{3}$ injection. 


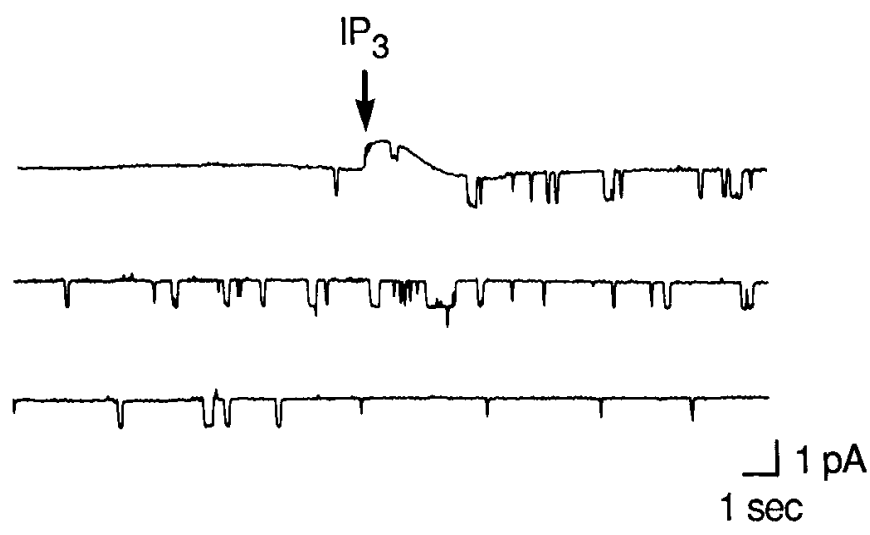

Figure 8. Effect of $\mathrm{IP}_{3}$ injection on single-channel activity recorded from a cell-attached patch held at the resting potential. In this experiment, $\mathrm{IP}_{3}$ injection was followed by a burst of openings of a channel passing inward current.

potentials, with prolonged ( $>\sim 20 \mathrm{msec}$ ) openings now occurring at the resting potential. The open channel current-voltage relation for this $\mathrm{IP}_{3}$-induced channel displayed some outward rectification, as illustrated in Figure 7 . The slope conductance over the voltage range 0 to $+70 \mathrm{mV}$ from rest was $\sim 40 \mathrm{pS}$, and the extrapolated reversal potential ( $37 \mathrm{mV}$ negative to rest) was close to that predicted for potassium ions. Similar results were obtained in 3 experiments in which the $\mathrm{IP}_{3}$ response was examined at multiple holding potentials.

A response similar to that following $\mathrm{IP}_{3}$ injection was also observed on injection of calcium ions. Twelve injections of calcium chloride in 5 cells increased the activity of channels passing outward current, recorded at patch potentials between rest and $86 \mathrm{mV}$ positive to rest. The latency of the response to calcium injections ranged between 2 and $25 \mathrm{sec}$, and the duration of the response varied between 3 and $200 \mathrm{sec}$.

In addition to increasing the activity of the channel described above, $\mathrm{IP}_{3}$ could also evoke openings of a channel passing inward current. Four injections of $\mathrm{IP}_{3}$ in 3 cells elicited sharp increases in the activity of such a channel, whose openings in the absence of $\mathrm{IP}_{3}$ were observed only rarely. One example of this is shown in Figure 8. A channel carrying $1 \mathrm{pA}$ of inward current at the resting potential opened numerous times during a period of $35 \mathrm{sec}$ postinjection, whereas before injection and after this $35 \mathrm{sec}$ burst the channel opened very rarely. Because this response was seen so infrequently, it was not investigated in more detail.

Recordings made from cell-free inside-out patches revealed at least one calcium-activated potassium channel, with prop- erties that match those of the $\mathrm{IP}_{3}$-modulated channel observed in cell-attached patches. When the inner surface of the membrane was bathed in solutions containing $10^{-9}, 10^{-8}, 10^{-7}$, and $10^{-6} \mathrm{M}$ calcium chloride, we observed channels whose probability of opening increased with calcium concentration. With $570 \mathrm{~mm} \mathrm{~K}^{+}$ions at the cytoplasmic face of the patches, the slope conductance of calcium-activated potassium channels we observed most often ( 5 out of 7 patches) averaged $60 \mathrm{pS}$ over the voltage range -100 to $0 \mathrm{mV}$. We examined the effect of exposing the internal surface of the membrane to $\mathrm{IP}_{3}$, and found that it did not induce increased channel activity in cell-free patches containing calcium-activated potassium channels $(n=$ 3) (not shown)

\section{Calcium imaging}

The electrophysiological effects of $\mathrm{IP}_{3}$ are consistent with the hypothesis that $\mathrm{IP}_{3}$ induces an elevation of intracellular calcium concentration in bag cell neurons. To test this hypothesis directly, we used isolated bag cell neurons loaded with the calcium indicator fura-2 (Grynkiewicz et al., 1985) to examine the effects of electrical stimulation and of $\mathrm{IP}_{3}$ injection on intracellular calcium levels. The responses to $\mathrm{IP}_{3}$ injection were tested in 11 cclls, using both iontophoretic and pressure-injection techniques. $\mathrm{IP}_{3}$ was injected intracellularly into bag cells using a single $1 \mathrm{sec}$ pulse or a series of repeated pulses at approximately $0.5 \mathrm{~Hz}$ (Figs. 9, 10). Twenty-four out of 25 injections of $\mathrm{IP}_{3}$ elicited significant increases in intracellular calcium in these neurons. The magnitude of these increases in the calcium signal varied between 10 and $400 \%$ (ratio of fluorescence images taken at 340 and $380 \mathrm{~nm}$ excitation), and depended on the number of injections, the electrode size, and the use of pressure or iontophoretic injection. Not surprisingly, the largest responses were obtained with longer pressure injection through large microelectrodes. Pressure injection of $\mathrm{KCl}$ alone had no effect on intracellular calcium concentrations.

To investigate whether the $\mathrm{IP}_{3}$-induced elevation of cytosolic calcium occurred through release from intracellular stores or entry across the plasma membrane, we injected $\mathrm{IP}_{3}$ into 3 cells bathed in calcium-free medium. Figure 9 illustrates that, in the absence of extracellular calcium, a single, 1 sec injection of $\mathrm{IP}_{3}$, comparable to that used in the electrophysiological experiments, evoked a significant increase in the cytosolic calcium signal. Before injection (Fig. 9a), calcium levels were around $300 \mathrm{~nm}$. Immediately following the injection of $\mathrm{IP}_{3}$, a gradient of intracellular calcium was recorded, with the greatest increase occurring near the electrode tip (793 nM). Intcrmcdiatc calcium levels of -415-536 nM were found elsewhere in the soma, and only a very slight increase was detected in the processes furthest from

\footnotetext{
Figure 9. Effects of $\mathrm{IP}_{3}$ injection on the intracellular $\left[\mathrm{Ca}^{2+}\right]$ of a fura-2-loaded bag cell neuron in calcium-free medium. On the left is a Nomarski image of the cell. The boxes on the cell indicate 3 locations in which the fluorescence ratio was measured. Ratios have been converted to approximate calcium concentrations. Locations will be referred to as 1,2 , and 3 , beginning with the box closest to the microelectrode at the left side of the cell and going clockwise. $a$, The increase in intracellular calcium evoked by a single injection of $\mathrm{IP}_{3}$, comparable to that used in the electrophysiological experiments (Figs. 2, 3, 5, 6). In the resting (control) image, calcium levels are (1) $356 \mathrm{~nm}$, (2) $273 \mathrm{nM}$, and (3) $296 \mathrm{~nm}$. Immediately following the $1 \mathrm{sec}$ injection of $\mathrm{IP}_{3}$, calcium levels rise to (1) $793 \mathrm{~nm}$, (2) $536 \mathrm{nM}$, and (3) $415 \mathrm{~nm}$. Fifteen seconds after the injection, they have risen further in the soma: (1) $861 \mathrm{nM}$, (2) $793 \mathrm{nM}$, and (3) $727 \mathrm{nM}$. Eighty seconds after the injection, calcium levels revert to control values: (1) $356 \mathrm{nM}$, (2) 296 $\mathrm{nM}$, and (3) $356 \mathrm{nM} . b$, The effect of multiple injections of $\mathrm{IP}_{3}$ in calcium-free medium. Values in the control are (1) $171 \mathrm{nM},(2) 132 \mathrm{nM}$, and (3) $132 \mathrm{nM}$. Immediately following $15 \mathrm{sec}$ of repetitive $\mathrm{IP}_{3}$ injections, they rise to (1) $1.30 \mu \mathrm{M},(2) 1.46 \mu \mathrm{M}$, and (3) $930 \mathrm{nM}$. Progressive recovery is evident $45 \mathrm{sec}$ after the injections: (1) $930 \mathrm{nM}$, (2) $793 \mathrm{nM}$, and (3) $598 \mathrm{nM}$; and, 2 min after the injections, (1) $356 \mathrm{nM}$, (2) $296 \mathrm{nM}$, and (3) 270 $\mathrm{nM}$. The top of the color scale represents a fluorescence ratio of $2.5(1.30 \mu \mathrm{M})$ in $a$ and $2.8(1.54 \mu \mathrm{M})$ in $b$.
} 

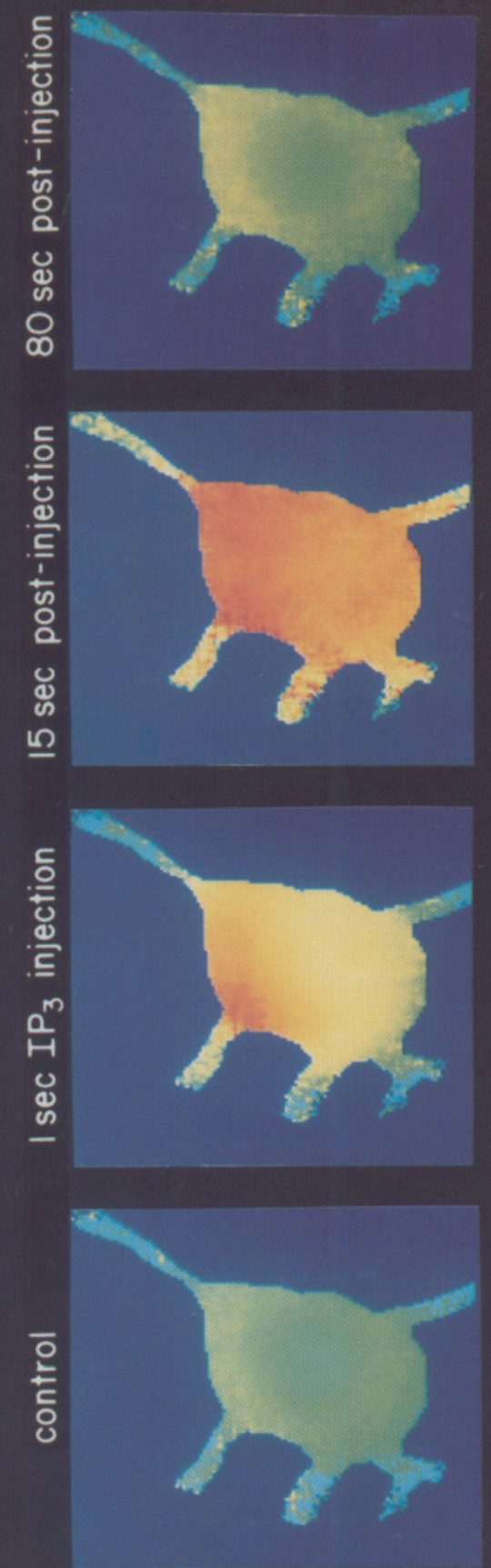

రं
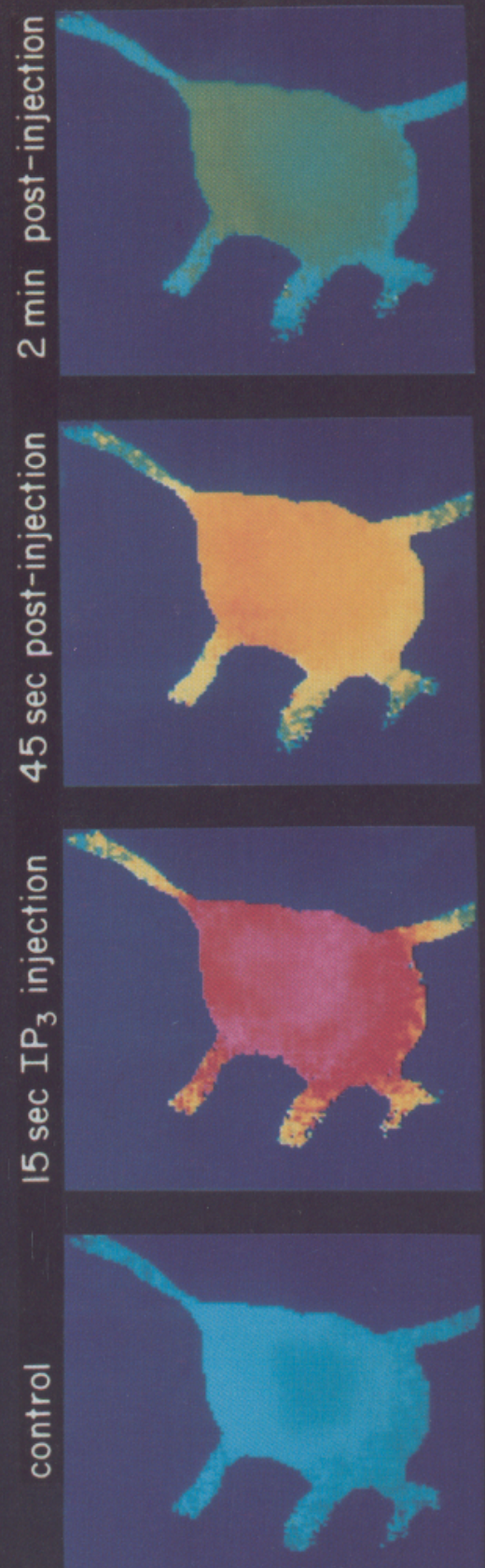
the injection site. Fifteen seconds after the injection, the calcium signal was further elevated and was relatively uniform in all regions of the soma (727-861 $\mathrm{nm}$ ). Recovery to control calcium levels (around $330 \mathrm{~nm}$ ) occurred within $80 \mathrm{sec}$ after $\mathrm{IP}_{3}$ injection.

Figure $9 b$ demonstrates that injecting a greater quantity of $\mathrm{IP}_{3}$ produced a larger increase in intracellular calcium. The calcium concentration in the soma rose to over $1 \mu \mathrm{M}$, as compared to 132-171 nM before injection. Moreover, even after multiple injections of $\mathrm{IP}_{3}$, the response was still preferentially localized to the soma, although smaller increases were recorded in the processes. Eighty percent recovery of calcium levels was observed $2 \mathrm{~min}$ after the end of the injections. Pressure injection of $\mathrm{KCl}$ had no effect on the calcium signal.

The spatial distribution of calcium elevation following $\mathrm{IP}_{3}$ injection could be clearly differentiated from that seen after depolarizing current injection in cells bathed in calcium-containing media, especially when neurite outgrowth had occurred. Acutely dissociated bag cell neurons are spherical, or spherical with short stumps of neurite attached, but by the second day in culture have usually sprouted considerable neuritic outgrowth (Kaczmarek et al., 1979). Immediately following electrical stimulation in such day 2 cells, a large increase in the calcium signal could be recorded in the neurites with little or no effect visible in the cell body. This behavior was in sharp contrast with that observed before neurites had sprouted ( $0-4 \mathrm{hr}$ after dissociation). During that period, large calcium transients could be evoked in the soma by the same number of action potentials (not shown). Figure $10 a$ shows the changes in calcium following a train of 15 action potentials in an isolated neuron in culture. Immediately following stimulation, a marked increase in the calcium signal could be recorded in the neurites, with a significantly smaller increase occurring in the soma.

Figure $10 b$ compares the effect of electrical stimulation with that of $\mathrm{IP}_{3}$ injection in the same cell. The Nomarski image of the cell shows numerous fine processes extending from the soma. The control fluorescence ratio image of the cell after penetration with an $\mathrm{IP}_{3}$-containing microelectrode shows the resting level of calcium to be uniformly low in soma $(\sim 260 \mathrm{~nm})$ and processes. After electrical stimulation of 25 action potentials (4/ sec), a dramatic rise in the calcium concentration occurred almost exclusively in the processes $(\sim 1 \mu \mathrm{M})$. The final image in the series illustrates the effect of 7 repetitive $\mathrm{IP}_{3}$ injections $(20$ psi, $1 \mathrm{sec}, 0.5 \mathrm{~Hz}$ ). The elevation of calcium was localized within the soma, reaching approximately $530 \mathrm{nM}$, and in contrast to the effect of depolarizing current injection, the processes were relatively unaffected. This was a consistent feature of all $11 \mathrm{IP}_{3}$ injected cells, in which calcium increases within the soma were accompanied only by much smaller changes or no change in the neurites.

In addition to differences between the intracellular distributions of responses to $\mathrm{IP}_{3}$ injection and to depolarization, there were also differences in the time course of the 2 responses. The increase in calcium concentration following $\mathrm{IP}_{3}$ injection was rapid in onset and continucd to risc for many seconds after the end of injection before declining to preinjection levels (see Fig. 9 a). In comparison, the response to one or more depolarizing current pulses began to decline immediately after stimulation. Elevated calcium levels following electrical stimulation usually recovered within $20-40 \mathrm{sec}$, whereas the response following $\mathrm{IP}_{3}$ injection lasted for 1-3 $\mathrm{min}$.

\section{Discussion}

Our studies have provided a direct demonstration that IP $\mathrm{I}_{3}$ acts to elevate intracellular calcium ions within neuronal somata, and that this effect is largely independent of extracellular calcium. Previous work on $\mathrm{IP}_{3}$ actions in intact, excitable cells has provided indirect evidence for such an elevation using electrophysiological techniques (Brown et al., 1984; Fein et al., 1984; I Iigashida et al., 1986; Sawada et al., 1987). Therefore, with respect to this important control mechanism, neurons closely resemble nonexcitable cells in which this pathway has been investigated in detail (Berridge, 1983; Streb et al., 1983; Burgess et al., 1984, 1985; Gershengorn et al., 1984; Prentki et al., 1984).

Our data also suggest that $\mathrm{IP}_{3}$ formation plays a role in the onset of the afterdischarge in the bag cell neurons. Previous work with these cells (Kaczmarek et al., 1978) has shown that stimuli that trigger discharges result in an elevation of cAMP levels, and that such elevations produce a variety of effects on potassium conductances, which promote the ability of these cells to afterdischarge (Kaczmarek and Strumwasser, 1981, 1984; Strong, 1984; Strong and Kaczmarek, 1986). We have now found that stimuli capable of triggering the bag cell neurons to discharge also induce hydrolysis of phosphoinositides. Not only are electrical stimulation of the connective nerve and exposure to atrial gland cxtract able to stimulate phosphoinositide metabolism in the bag cell neurons, but exposure of the cells to forskolin and theophylline, a treatment that directly elevates cAMP levels in these cells, also increases phosphoinositide turnover. The mechanism by which forskolin/theophylline stimulates phosphoinositide metabolism in the bag cell neurons is not yet known. It could be that an elevation of cAMP directly influences enzymes involved in phosphoinositide turnover. Alternatively, since these agents can trigger discharges, phosphoinositide metabolism could be stimulated indirectly by substances released from the bag cell neurons during a discharge.

The mobilization of intracellular calcium by $\mathrm{IP}_{3}$ could influence a variety of cellular processes at the onset of the afterdischarge in the bag cell neurons. In addition to promoting the secretion of neuroactive peptides from these neurons, an elevation of calcium would be expected to promote the activity of calcium-dependent enzymes, such as the calcium/calmodulinand calcium/phospholipid-dependent protein kinases (DeRiemer et al., 1984, 1985a). The activation of the latter protein kinase enhances voltage-dependent calcium current (DeRiemer et al., 1985b; Strong et al., 1987) and contributes to the subsequent transformation of the electrical properties of the bag cell neurons. The pattern of a transient cellular response to IP followed by a sustained response to protein kinase $\mathrm{C}$ activation

\footnotetext{
Figure 10. Effects of electrical stimulation and $\mathrm{IP}_{3}$ injection on the intracellular calcium concentration of isolated bag cell neurons loaded with fura-2. a, Digitized images of the ratio of fluorescence at 340 and $380 \mathrm{~nm}$ excitation, reflecting the intracellular distribution of Ca ${ }^{2+}$ ions. Center, The calcium signal following a train of 15 action potentials. $b$, Left, the transmitted light (Nomarski) image of a different cell. The next 3 panels show the fluorescence ratio images before stimulation (control), following 25 action potentials, and immediately after 7 injections of $\mathrm{IP}_{3}$ at $0.5 \mathrm{~Hz}$. Cells shown had been cultured the previous day. The vertical color scale at the right represents the fluorescence ratio values, with the top of the scale (pink) equal to a maximum ratio of 2.5 .
} 


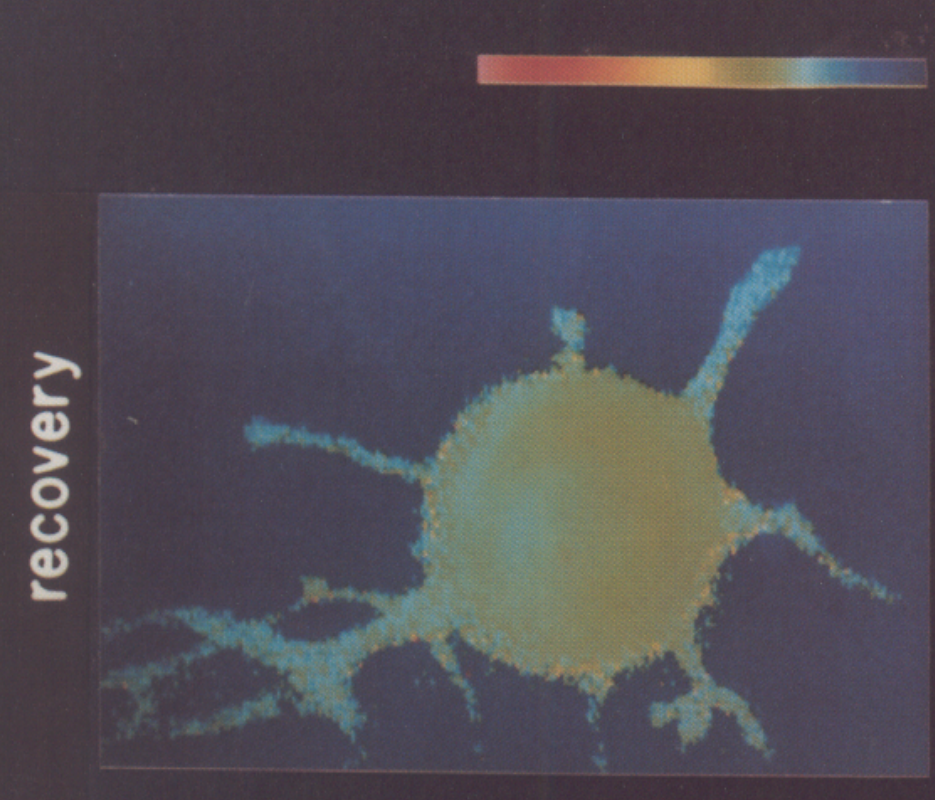

$$
\frac{\text { 등 }}{\frac{0}{0}}
$$

$\frac{\frac{0}{0}}{\frac{5}{0}}$
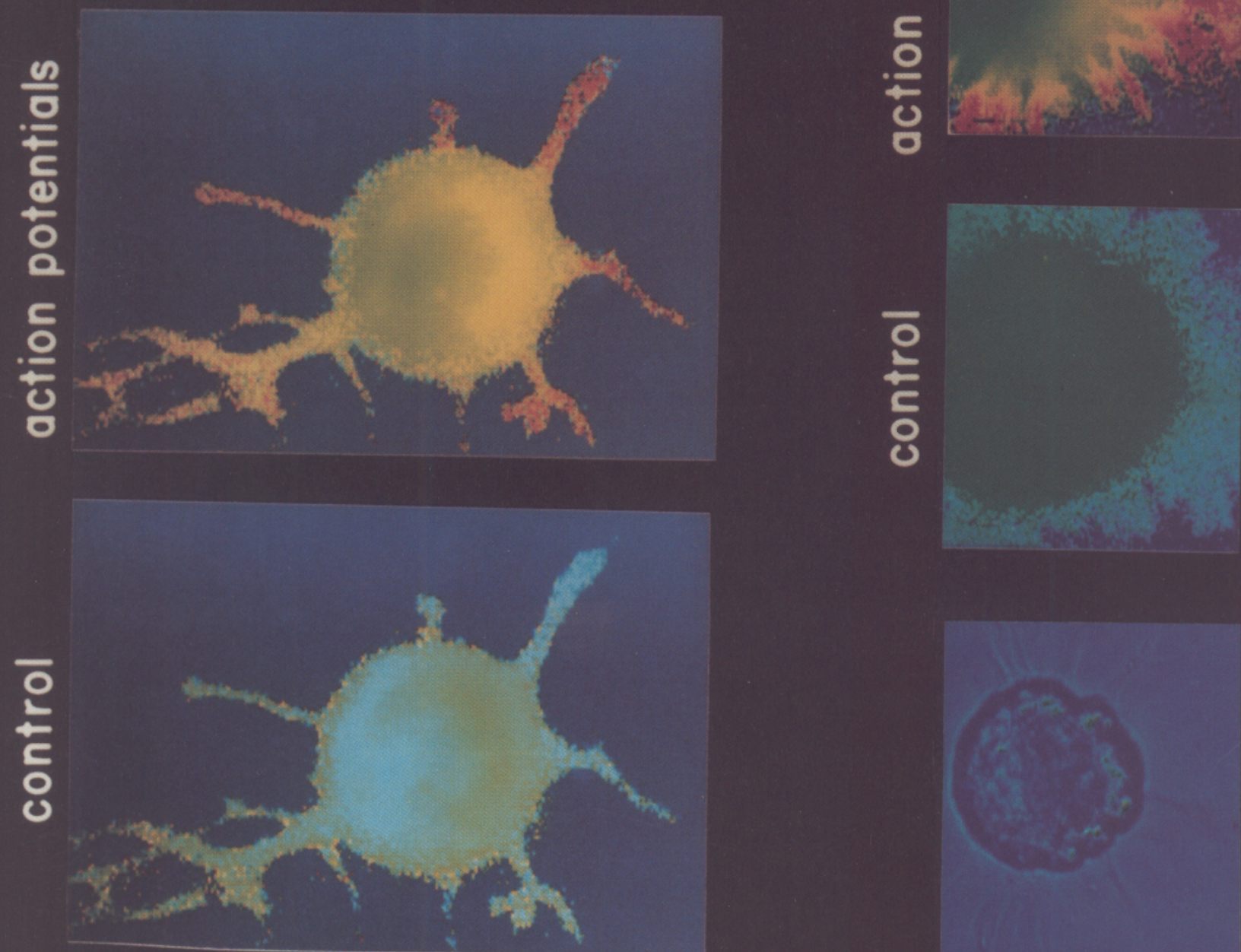

ఠ 
has been suggested for the agonist-induced stimulation of a variety of non-neuronal cell types. For example, synergistic actions of calcium and protein kinase $C$ appear to underlie the physiological response to cellular stimulation of pituitary cells (Delbeke et al., 1984), adrenal glomerulosa cells (Kojima et al., 1984), and pancreatic beta cells (Zawalich et al., 1983). Our study suggests that a similar synergism between $\mathrm{IP}_{3}$ and protein kinase $\mathrm{C}$ may contribute to the prolonged electrical and neurosecretory activity that results from brief synaptic stimulation of these cells, leading to the initiation of a series of reproductive behaviors in the animal.

The electrophysiological effects of $\mathrm{IP}_{3}$ injection are consistent with those expected to result from an $\mathrm{IP}_{3}$-induced release of intracellular calcium. A major component of the potassium current in bag cell neurons has been shown to be calcium dependent (Kaczmarek and Strumwasser, 1984; Strong and Kaczmarek, 1986). The activation of a calcium-dependent potassium conductance would be expected to produce a hyperpolarization and a decrease in input resistance, as was seen in response to $\mathrm{IP}_{3}$ injection. The decrease in input resistance could contribute to the attenuation of action potentials. Moreover, an elevation of intracellular calcium could also produce calcium-dependent inactivation of calcium current (Eckert and Tillotson, 1981), further attenuating action potentials, which, in bag cell ncurons, have a large calcium component (Kaczmarek and Strumwasser, 1984; DeRiemer et al., 1985b). In single-channel recordings, the major response to $\mathrm{IP}_{3}$ injection was the opening of a channel whose properties resemble those of calcium-activated potassium channels described in other preparations. In particular, the shift in voltage-dependence of the probability of channel opening to more negative potentials that we observed in response to $\mathrm{IP}_{3}$ has been demonstrated for calcium-activated potassium channels from a variety of sources in response to an elevation of calcium concentration at the cytoplasmic face of the channel (Lux et al., 1981; Moczydlowski and Latorre, 1983; Ewald and Levitan, 1987; Miller, 1987). Further supporting the hypothesis that the effects of $\mathrm{IP}_{3}$ are mediated indirectly through the release of intracellular calcium, we found that injection of calcium ions mimicked the responses seen after $\mathrm{IP}_{3}$ injection. In addition, we found no direct effect of $\mathrm{IP}_{3}$ on the opening of outward channels in cell-free patches from bag cell neurons.

In a few experiments, $\mathrm{IP}_{3}$ also increased the activity of a channel carrying inward current at the resting potential. One possible explanation is that the bag cell membrane contains a calcium-activated, nonspecific cation channel (Yellen, 1982). Alternatively, $\mathrm{IP}_{3}$ may act on the membrane itself to open a cation-permeable channel, perhaps an $\mathrm{IP}_{3}$-sensitive calcium channel, as has been described for T-lymphocytes (Kuno and Gardner, 1987).

Fluorescence images of cells preloaded with the calcium indicator fura- 2 confirmed that $\mathrm{IP}_{3}$ injection produces a sharp rise in cytosolic calcium in the somata of these neurons. This response to $\mathrm{IP}_{3}$ was not affected by removal of extracellular calcium. Thus, we conclude that $\mathrm{IP}_{3}$ elevates cytosolic calcium through release from intracellular stores. It is possible that calcium-induced calcium release also contributes to the progressive elevation of calcium following $\mathrm{IP}_{3}$ injection (Fabiato, 1982). The elevated levels of calcium evoked by $\mathrm{IP}_{\uparrow}$ injection were localized primarily to the somata, although smaller changes in calcium concentration could be observed in the neurites. This pattern is in sharp contrast to that seen with electrical stimulation of bag cell neurons in calcium-containing medium. There are several possible reasons why $\mathrm{IP}_{3}$ elevates calcium levels in the neurites to a much smaller extent than in the soma. It is unlikely that $\mathrm{IP}_{3}$ fails to reach the neurites because of simple diffusional barriers, as we have observed that a variety of fluorescent dyes rapidly fill both the somata and neurites following intracellular injection. It is possible, however, that neurites contain a significantly lower density of calcium storage sites, or that hydrolysis of $\mathrm{IP}_{3}$ limits its entry into the neurites.

\section{References}

Berridge, M. J. (1983) Rapid accumulation of inositol trisphosphate reveals that agonists hydrolyse polyphosphoinositides instead of phosphatidylinositol. Biochem. J. 212: 849-858.

Berridge, M. J. (1984) Inositol trisphosphate and diacylglycerol as second messengers. Biochem. J. 220: 345-360.

Berridge, M. J., and R. F. Irvine (1984) Inositol trisphosphate, a novel second messenger in cellular signal transduction. Nature 312: 315321.

Berridge, M. J., C. P. Downes, and M. R. Hanley (1982) Lithium amplifies agonist-dependent phosphatidylinositol responses in brain and salivary glands. Biochem. J. 206: 587-595.

Berridge, M. J., R. M. C. Dawson, C. P. Downes, J. P. Heslop, and R. F. Irvine (1983) Changes in the levels of inositol phosphates after agonist-dependent hydrolysis of membrane phosphoinositides. Biochem. J. 212: 473-482.

Brown, J. E., L. J. Rubin, A. J. Ghalayini, A. P. Tarver, R. F. Irvine, M. J. Berridge, and R. E. Anderson (1984) Myo-inositol polyphosphate may be a messenger for visual excitation in Limulus photoreceptors. Nature 311: 160-163.

Burgess, G. M., P. P. Godfrey, J. S. McKinney, M. J. Berridge, R. F. Irvine, and J. W. Putney, Jr. (1984) The second messenger linking receptor activation to internal $\mathrm{Ca}$ release in liver. Nature 309: 6366.

Burgess, G. M., J. S. McKinney, R. F. Irvine, and J. W. Putney, Jr. (1985) Inositol 1,4,5-trisphosphate and inositol 1,3,4-trisphosphate formation in $\mathrm{Ca}^{2+}$-mobilizing-hormone-activated cells. Biochem. J. 232: $237-243$

Connor, J. A. (1986) Digital imaging of free calcium changes and of spatial gradients in growing processes in single, mammalian central nervous system cells. Proc. Natl. Acad. Sci. USA 83: 6179-6183.

Connor, J. A., and P. Hockberger (1984) A novel membrane sodium current induced by injection of cyclic nucleotides into gastropod neurones. J. Physiol. (Lond.) 354: 139-162.

Connor, J. A., M. C. Cornwall, and G. H. Williams (1987a) Spatially resolved cytosolic calcium response to angiotensin II and potassium in rat glomerulosa cells measured by digital imaging techniques. $\mathrm{J}$. Biol. Chem. 262: 2919-2927.

Connor, J. A., H. Tseng, and P. E. Hockberger (1987b) Depolarization and transmitter induccd changes in intracellular $\mathrm{Ca}^{2+}$ of rat cerebellar granule cells in explant cultures. J. Neurosci. 7: 1384-1400.

Delbeke, D., I. Kojima, P. S. Dannies, and H. Rasmussen (1984) Synergistic stimulation of prolactin release by phorbol ester, A23187 and forskolin. Biochem. Biophys. Res. Commun. 123: 735-741.

DeRiemer, S. A., L. K. Kaczmarek, Y. Lai, T. L. McGuinness, and P. Greengard (1984) Calcium/calmodulin-dependent protein phosphorylation in the nervous system of Aplysia. J. Neurosci. 4: 16181625 .

DeRiemer, S. A., P. Greengard, and L. K. Kaczmarek (1985a) Calcium/diacyglycerol/phosphatidyl serine dependent protein phosphorylation in the Aplysia nervous system. J. Neurosci. 5: 2672-2676.

DeRiemer, S. A., J. A. Strong, K. A. Albert, P. Greengard, and L. K. Kaczmarek (1985b) Enhancement of calcium current in Aplysia neurons by phorbol ester and protein kinase C. Nature 313: 313-316.

Dudek, F. E., and J. E. Blankenship (1977) Neuroendocrine cells of Aplysia brasiliana. I. Bag cell action potentials and afterdischarge. $\mathrm{J}$. Neurophysiol. 40: 1301-1311.

Dudek, F. E., J. S. Cobbs, and H. M. Pinsker (1979) Bag cell electrical activity underlying spontaneous egg laying in freely behaving Aplysia brasiliana. J. Neurophysiol. 42: 804-817.

Eckert, R., and D. Tillotson (1981) Calcium-mediated inactivation of calcium conductance in caesium-loaded giant neurons of Aplysia californica. J. Physiol. (Lond.) 314: 265-280.

Ewald, D. A., and I. B. Levitan (1987) Ion channels regulated by 
calcium. In Neuromodulation: The Biochemical Control of Neuronal Excitability, L. K. Kaczmarek and I. R. Levitan, eds., Oxford U. P., New York.

Fabiato, A. (1982) Calcium release in skinned cardiac cells: Variations with species, tissues and development. Fed. Proc. 41: 2238-2244.

Fein, A., R. Payne, D. W. Corson, M. J. Berridge, and R. F. Irvine (1984) Photoreceptor excitation and adaptation by inositol 1,4,5trisphosphate. Nature 311: 157-160.

Gershengorn, M. C., E. Geras, V. S. Purrello, and M. J. Rebecchi (1984) Inositol trisphosphate mediates thyrotropin-releasing hormone mobilization of nonmitochondrial calcium in rat mammotropic pituitary cells. J. Biol. Chem. 259: 10675-10681.

Grynkiewicz, G., M. Poenie, and R. Y. Tsien (1985) A new generation of $\mathrm{Ca}^{2+}$ indicators with greatly improved fluorescence properties. J. Biol. Chem. 260: 3440-3450.

Hamill, O. P., A. Marty, E. Neher, B. Sakmann, and F. J. Sigworth (1981) Improved patch-clamp techniques for high resolution recording from cells and cell-free membrane patches. Pfluegers Arch. 391: $85-100$.

Heller, E., L. K. Kaczmarek, M. W. Hunkapiller, L. E. Hood, and F. Strumwasser (1980) Purification and primary structure of two neuroactive peptides that cause bag cell afterdischarge and egg-laying in Aplysia. Proc. Natl. Acad. Sci. USA 77: 2328-2332.

Higashida, H., R. A. Streaty, W. Klee, and M. Nirenberg (1986) Bradykinin-activated transmembrane signals are coupled via $\mathrm{N}_{0}$ or $\mathrm{N}_{\mathrm{i}}$ to production of inositol 1,4,5-trisphosphate, a second messenger in NG108-15 neuroblastoma-glioma hybrid cells. Proc. Natl. Acad. Sci. USA 83: 942-946.

Jennings, K. R., L. K. Kaczmarek, R. M. Hewick, W. J. Dreyer, and F. Strumwasser (1982) Protein phosphorylation during afterdischarge in peptidergic neurons of Aplysia. J. Neurosci. 2: 158-168.

Kaczmarek, L. K., and J. A. Kauer (1983) Calcium entry causes a prolonged refractory period in peptidergic neurons of Aplysia. J. Neurosci. 3: 2230-2239.

Kaczmarek, L. K., and F. Strumwasser (1981) The expression of longlasting afterdischarge by isolated Aplysia bag cell neurons. J. Neurosci. 1: 626-634.

Kaczmarek, L. K., and F. Strumwasser (1984) A voltage-clamp analysis of currents underlying cyclic AMP-induced membrane modulation in isolated peptidergic neurons of Aplysia. J. Neurophysiol. 52: 340-349.

Kaczmarek, L. K., K. Jennings, and F. Strumwasser (1978) Neurotransmitter modulation, phosphodiesterase inhibitor effects, and cyclic AMP correlates of afterdischarge in peptidergic neurites. Proc. Natl. Acad. Sci. USA 75: 5200-5204.

Kaczmarek, L. K., M. Finbow, J. P. Revel, and F. Strumwasser (1979) The morphology and coupling of Aplysia bag cells within the abdominal ganglion and in cell culture. J. Neurobiol. 10: 535-550.

Kaczmarek, L. K., K. R. Jennings, F. Strumwasser, A. C. Nairn, U. Walter, F. D. Wilson, and P. Greengard (1980) Microinjection of catalytic subunit of cyclic AMP-dependent protein kinase enhances calcium action potentials of bag cell neurons in cell culture. Proc. Natl. Acad. Sci. USA 77: 7427-7491.

Kaczmarek, L. K., K. R. Jennings, and F. Strumwasser (1982) An early sodium and a late calcium phase in the afterdischarge of peptide secreting neurons of Aplysia. Brain Res. 238: 105-115.

Kauer, J. A., and L. K. Kaczmarek (1985) Peptidergic neurons of
Aplysia lose their response to cyclic adenosine $3^{\prime}: 5^{\prime}$-monophosphate during a prolonged refractory period. J. Neurosci. 5: 1339-1345.

Kojima, I., K. Kojima, D. Kreutter, and H. Rasmussen (1984) The temporal integration of the aldosterone secretory response to angiotensin occurs via two intracellular pathways. J. Biol. Chem. 259. 14448-14457.

Kuno, M., and P. Gardner (1987) Ion channels activated by inositol 1,4,5-trisphosphate in plasma membrane of human T-lymphocytes. Nature 326: 301-304.

Kupfermann, I., and E. R. Kandel (1970) Electrophysiological properties and functional interconnections of two symmetrical neurosecretory clusters (bag cells) in the abdominal ganglion of Aplysia. J. Neurophysiol. 33: 865-876.

Lux, H. D., E. Neher, and A. Marty (1981) Single channel activity associated with the calcium-dependent outward current in Helix pomatia. Pfluegers Arch. 389: 293-295.

Miller, C. (1987) How ion channels work. In Neuromodulation: The Biochemical Control of Neuronal Excitability, L. K. Kaczmarek and I. R. Levitan, eds., Oxford U. P., New York.

Moczydlowski, E., and R. Latorre (1983) Gating kinetics of $\mathrm{Ca}^{++}$ activated $\mathrm{K}^{+}$channels from rat muscle incorporated into planar lipid bilayers: Evidence for two voltage-dependent $\mathrm{Ca}^{++}$binding reactions. J. Gen. Physiol. 82: 511-542.

Nishizuka, Y. (1984) The role of protein kinase $C$ in cell surface signal transduction and tumour promotion. Nature 308: 693-697.

Prentki, M., T. J. Biden, D. Janjic, R. F. Irvine, M. J. Berridge, and C. B. Wollheim (1984) Rapid mobilization of $\mathrm{Ca}^{2+}$ from rat insulinoma microsomes by inositol-1,4,5-trisphosphate. Nature 309: 562-564.

Sawada, M., M. Ichinose, and T. Maeno (1987) Ionic mechanism of the outward current induced by intracellular injection of inositol trisphosphate into Aplysia neurons. J. Neurosci. 7: 1470-1483.

Streb, H., R. F. Irvine, M. J. Berridge, and I. Schulz (1983) Release of $\mathrm{Ca}^{2+}$ from a nonmitochondrial intracellular store in pancreatic acinar cells by inositol-1,4,5-trisphosphate. Nature 306: 67-69.

Strong, J. A. (1984) Modulation of potassium current kinetics in bag cell neurons of Aplysia by an activator of adenylate cyclase. J. Neurosci. 4: 2772-2783.

Strong, J. A., and L. K. Kaczmarek (1986) Multiple components of delayed potassium current in peptidergic neurons of Aplysia: Modulation by an activator of adenylate cyclase. J. Neurosci. 6: 814-822.

Strong, J. A., A. P. Fox, R. W. Tsien, and L. K. Kaczmarek (1987) Stimulation of protein kinase $\mathrm{C}$ recruits covert calcium channels in Aplysia bag cell neurons. Nature 325: 714-717.

Tsien, R. Y., and M. Poenie (1986) Fluorescence ratio imaging: A new window into intracellular ionic signalling. Trends Biosci. 11: 450455.

Tsien, R. Y., T. J. Rink, and M. Poenie (1985) Measurement of cytosolic free $\mathrm{Ca}^{2+}$ in individual small cells using fluorescence microscopy with dual excitation wavelengths. Cell Calcium 6: 145-157.

Williams, D. A., K. E. Fogarty, R. Y. Tsien, and F. S. Fay (1985) Calcium gradients in single smooth muscle cells revealed by the digital imaging microscope using fura-2. Nature 318: 558-561.

Yellen, G. (1982) Single $\mathrm{Ca}^{++}$-activated nonselective cation channels in neuroblastoma. Nature 296: 357-359.

Zawalich, W., C. Brown, and H. Rasmussen (1983) Insulin secretion: Combined effect of phorbol ester and A23187. Biochem. Biophys. Res. Commun. 117: 448-455. 